\title{
Diseases affect cold-water corals too: Eunicella verrucosa (Cnidaria: Gorgonacea) necrosis in SW England
}

\author{
Jason M. Hall-Spencer*, James Pike, Colin B. Munn \\ Marine Institute, University of Plymouth, Plymouth PL4 8AA, UK
}

\begin{abstract}
The first recorded incidence of cold-water coral disease was noted in Eunicella verrucosa, a coral on the international 'red list' of threatened species, at a marine protected area in SW England in 2002. Video surveys of 634 separate colonies at 13 sites revealed that disease outbreaks were widespread in SW England from 2003 to 2006. Coenchyme became necrotic in diseased specimens, leading to tissue sloughing and exposing skeletal gorgonin to settlement by fouling organisms. Sites where necrosis was found had significantly higher incidences of fouling. No fungi were isolated from diseased or healthy tissue, but significantly higher concentrations of bacteria occurred in diseased specimens. Of 21 distinct bacteria isolated from diseased tissues, 19 were Vibrionaceae, 15 were strains of Vibrio splendidus and 2 others closely matched Vibrio tasmaniensis. Vibrios isolated from $E$. verrucosa did not induce disease at $15^{\circ} \mathrm{C}$, but, at $20^{\circ} \mathrm{C}$, controls remained healthy and test gorgonians became diseased, regardless of whether vibrios were isolated from diseased or healthy colonies. Bacteria associated with diseased tissue produced proteolytic and cytolytic enzymes that damaged E. verrucosa tissue and may be responsible for the necrosis observed. Monitoring at the site where the disease was first noted showed new gorgonian recruitment from 2003 to 2006; some individuals had died and become completely overgrown, whereas others had continued to grow around a dead central area.
\end{abstract}

KEY WORDS: Cold-water coral $\cdot$ Disease $\cdot$ Gorgonian $\cdot$ NE Atlantic - Resale or republication not permitted without written consent of the publisher

\section{INTRODUCTION}

Study of disease in warm-water corals is a major research area because of its growing incidence in tropical and Mediterranean waters with widespread concerns over the deleterious knock-on effects on biodiversity, tourism and coastal defence (Harvell et al. 2002, Bruno et al. 2003, Linares et al. 2005, Ritchie 2006). However, there have been no previous studies on the diseases of cold-water corals, despite the prevalence and known importance of corals in the functional ecology of temperate and deep-sea environments (Guinotte et al. 2006, Roberts et al. 2006, Hall-Spencer et al. 2007).

Although reports of warm-water coral diseases have been on the increase, disease aetiology has only been established in a small number of cases (Rosenberg \& Ben Haim 2002, Munn 2004). One of the first coral diseases for which a clear microbial aetiology was confirmed is aspergillosis, which has caused localised outbreaks of disease in Caribbean populations of Gorgonia ventalina and G. flabellum since 1984, with mass mortalities recorded in 1994 (Kim \& Harvell 2004). The disease is characterised by thickened tissue and purple areas of necrosis caused by Aspergillus sydowii, a fungus found commonly in decaying matter in terrestrial environments (Nagelkerken et al. 1997, Geiser et al. 1998). It has been proposed that A. sydowii may be deposited in the Caribbean marine environment via dust storms from deserts in Africa (Garrison et al. 2003). The causes of diseases in other warm-water gorgonians are less well-known; the cyanobacterium Scytonema sp. has been associated with a disease in Caribbean Briareum asbestinum gorgonians during a bleaching event associated with high sea-surface temperatures, although it was not possible to determine if 
this cyanobacterium was the primary causative agent (Harvell et al. 2001). In the Mediterranean, Cerrano et al. (2000) reported extensive gorgonian mortality during unusually warm water conditions in 1999, which Martin et al. (2002) linked to infection by Vibrio spp. bacteria at elevated temperatures.

Against this background of a growing understanding of warm-water coral diseases, the present paper reports in situ and laboratory observations of a disease outbreak in cold-water populations of Eunicella verrucosa following preliminary reports of the disease at a well-monitored site at Lundy, a Marine Protected Area in SW England (Hiscock 2003). This gorgonian has a limited distribution around the British Isles and was historically collected for souvenirs so it is now one of the few marine species fully protected under the Wildlife and Countryside Act, 1981, and listed in the UK Biodiversity Action Plan. It is also listed as vulnerable on the International Union for Conservation of Nature and Natural Resources 'red list' of threatened species (IUCN 2006). The 3 main aims of the present study were to: (1) evaluate whether an outbreak in 2002 was an isolated incident, (2) to examine the nature of the disease and (3) to investigate the hypothesis that pathogenic microbes were responsible.

\section{MATERIALS AND METHODS}

Field observations. Destructive sampling was kept to a minimum because of the protected status of Eunicella verrucosa. Surveys of disease incidence were undertaken using a Sony PC-110 digital video camera held in a Sea \& Sea VXPC110 underwater housing during SCUBA dives along depth-stratified belt transects at sites known to support dense populations of the gorgonians based on interviews with local divers. Twelve sites were surveyed between 1 and 7 times in the English Channel, and 1 site was surveyed in the Lundy No Take Zone, Bristol Channel, from 2003 to 2006, allowing analysis of the incidence of disease in 634 separate gorgonian colonies (Table 1).

The camera was used to record all gorgonians encountered in a 25 min period along belt transects within depth contours of $\pm 1.5 \mathrm{~m}$. Still pictures were taken from the video showing perpendicular photoquadrats of each gorgonian next to a ruler for scale. The photographs were analysed to record prevalence of necrosis, and the degree of fouling by epibionts was recorded on a 3 -rank scale $(0=$ no overgrowth, $1=$ $<10 \%$ of gorgonian overgrown, $2=>10 \%$ of gorgonian overgrown) to test the hypothesis that fouling organisms were more prevalent on gorgonians at sites where necrosis was noted. Repeat surveys of the same gorgonians were made at Knoll Pins, Lundy, using obvious features of the submerged cliff and boulder field to relocate individuals, whereas different areas were sampled during repeat surveys at the other sites to ensure that the same individuals were not surveyed twice.

On 27 August 2003, divers collected the first 21 gorgonians encountered from a patch of specimens in various states of disease and overgrowth to identify their associated macrobiota at 19 to $22 \mathrm{~m}$ below chart datum on Mewstone Ledges $\left(50^{\circ} 18.15^{\prime} \mathrm{N}, 4^{\circ} 06.74^{\prime} \mathrm{W}\right)$ in accordance with a licence granted by English Nature. Each gorgonian was encased in a labelled plastic bag before using garden secateurs to cut through the stem and tying the bag closed. Samples were preserved in $4 \%$ seawater formalin and rinsed over a $0.2 \mathrm{~mm}$ sieve to retain larger epibiota. Attached species were removed under a dissecting microscope, identifying the various species present.

Histology. Clippings of $100 \mathrm{~mm}$ length were taken from the extremities of Eunicella verrucosa colonies collected at Mewstone Ledges on 18 August 2005. Each clipping was placed in zip-sealed plastic bags with seawater and returned to the laboratory in a cool box for processing within $3 \mathrm{~h}$ of collection. Samples were taken from healthy colonies and from the region where exposed skeleton met wasted tissue on diseased colonies; then, they were fixed in $2.5 \%$ gluteraldehyde in $10 \mu \mathrm{m}$ filtered and autoclaved artificial seawater (ASW, Instant Ocean) for 48 h. For SEM (scanning electron microscopy), samples were rinsed in ASW and then in distilled water (15 min each); they were dehydrated in an ethanol series, critical point dried (Emitech K550) and then frozen in liquid nitrogen before freeze-fracturing with a razor blade. Sclerites were disassociated from the tissue by macerating in sodium hypochlorite, repeatedly rinsing in water and finally rinsing in 95\% ethanol. Samples were mounted on stubs, gold sputter coated (Emitech K850) and observed in a JEOL 5600LV SEM. For light microscopy, clippings were decalcified in $10 \%$ EDTA adjusted to $\mathrm{pH} 7.0$ with $\mathrm{NaOH}$ for $24 \mathrm{~h}$ and dehydrated in graded alcohols, cleared in xylene and embedded in paraffin wax. Sections (4 to $6 \mu \mathrm{m}$ ) were cut using a rotary microtome after softening the gorgonin using a proprietary depilatory cream (Veet). Sections were stained using haematoxylin and eosin protocols (Bucke 1989) and examined using a Leica DM1RB.

Microbiology. Clippings of $20 \mathrm{~mm}$ length were rinsed repeatedly in sterile ASW, weighed and then ground with a sterile mortar and pestle with $1.0 \mathrm{ml}$ sterile ASW to remove soft tissues. The homogenate was removed, and the procedure was repeated 3 times to produce $3.0 \mathrm{ml}$ of homogenate prior to reweighing the clippings. Duplicate $0.1 \mathrm{ml}$ samples of 10 -fold serial dilutions in ASW of each homogenate were spreadplated onto: (1) malt extract agar (MEX, Oxoid) made 
Table 1. Site name, position, depth, bottom-water temperature and date of surveys showing total numbers of Eunicella verrucosa recorded and the proportion seen with necrosis. Shaded part of the table indicates sites at which necrosis was noted. Note: the same colonies were resurveyed at Knoll Pins; at other sites, different colonies were surveyed on repeat dives

\begin{tabular}{|c|c|c|c|c|c|c|}
\hline Site & Position & $\begin{array}{l}\text { Depth } \\
\text { (m) }\end{array}$ & $\begin{array}{l}\text { Temp. } \\
\left({ }^{\circ} \mathrm{C}\right)\end{array}$ & $\begin{array}{c}\text { Date } \\
\text { (dd.mm.yy) }\end{array}$ & $\begin{array}{l}\text { Number } \\
\text { recorded }\end{array}$ & $\begin{array}{l}\text { Number } \\
\text { necrotic }\end{array}$ \\
\hline \multicolumn{7}{|l|}{ Bristol Channel } \\
\hline Knoll Pins, Lundy & $51^{\circ} 11.28^{\prime} \mathrm{N}, 04^{\circ} 39.63^{\prime} \mathrm{W}$ & $24-27$ & $\begin{array}{l}10.6 \\
12.4 \\
15.1 \\
13.2\end{array}$ & $\begin{array}{l}02.05 .03 \\
19.06 .05 \\
06.08 .05 \\
03.06 .06\end{array}$ & $\begin{array}{l}18 \\
13 \\
12 \\
15\end{array}$ & $\begin{array}{l}4 \\
1 \\
0 \\
0\end{array}$ \\
\hline \multicolumn{7}{|l|}{ English Channel } \\
\hline Mewstone 1 & $50^{\circ} 18.168^{\prime} \mathrm{N}, 04^{\circ} 07.261^{\prime} \mathrm{W}$ & $19-24$ & $\begin{array}{l}12.4 \\
12.1\end{array}$ & $\begin{array}{l}11.06 .04 \\
11.11 .04\end{array}$ & $\begin{array}{l}10 \\
12\end{array}$ & $\begin{array}{l}6 \\
5\end{array}$ \\
\hline Mewstone 2 & $50^{\circ} 18.151^{\prime} \mathrm{N}, 04^{\circ} 06.742^{\prime} \mathrm{W}$ & $19-22$ & $\begin{array}{c}14.8 \\
15.3 \\
9.7 \\
9.9 \\
15.2 \\
15.2 \\
13.9\end{array}$ & $\begin{array}{l}19.07 .03 \\
27.08 .03 \\
21.01 .04 \\
26.01 .05 \\
16.08 .05 \\
18.08 .05 \\
20.10 .05\end{array}$ & $\begin{array}{l}30 \\
29 \\
28 \\
27 \\
30 \\
22 \\
24\end{array}$ & $\begin{array}{l}8 \\
8 \\
0 \\
0 \\
6 \\
2 \\
1\end{array}$ \\
\hline Breakwater Fort & $50^{\circ} 20.021^{\prime} \mathrm{N}, 04^{\circ} 08.881^{\prime} \mathrm{W}$ & $6-9$ & $\begin{array}{c}15.0 \\
15.2 \\
9.1 \\
12.8 \\
15.3\end{array}$ & $\begin{array}{l}22.07 .03 \\
28.08 .03 \\
23.03 .04 \\
26.06 .04 \\
16.08 .05\end{array}$ & $\begin{array}{l}20 \\
20 \\
20 \\
20 \\
31\end{array}$ & $\begin{array}{l}0 \\
0 \\
0 \\
6 \\
3\end{array}$ \\
\hline Beer Home Ground & $50^{\circ} 38.456^{\prime} \mathrm{N}, 03^{\circ} 03.367^{\prime} \mathrm{W}$ & $22-24$ & - & 18.07 .05 & 23 & 3 \\
\hline Saw-Tooth Ledges & $50^{\circ} 41.430^{\prime} \mathrm{N}, 02^{\circ} 47.389^{\prime} \mathrm{W}$ & $24-28$ & - & 19.07 .05 & 16 & 3 \\
\hline Lanes Ground & $50^{\circ} 40.320^{\prime} \mathrm{N}, 02^{\circ} 54.917^{\prime} \mathrm{W}$ & $23-26$ & - & 26.07 .05 & 12 & 1 \\
\hline James Egan Lane & $50^{\circ} 19.607^{\prime} \mathrm{N}, 04^{\circ} 14.702^{\prime} \mathrm{W}$ & $19-22$ & $\begin{array}{l}13.9 \\
14.1 \\
15.0\end{array}$ & $\begin{array}{l}29.10 .03 \\
13.07 .04 \\
14.08 .05\end{array}$ & $\begin{array}{l}23 \\
28 \\
24\end{array}$ & $\begin{array}{l}0 \\
0 \\
0\end{array}$ \\
\hline Persier & $50^{\circ} 17.102^{\prime} \mathrm{N}, 03^{\circ} 58.116^{\prime} \mathrm{W}$ & $24-27$ & $\begin{array}{l}14.5 \\
15.0\end{array}$ & $\begin{array}{l}18.07 .04 \\
17.09 .05\end{array}$ & $\begin{array}{l}25 \\
27\end{array}$ & $\begin{array}{l}0 \\
0\end{array}$ \\
\hline Drop Off & $50^{\circ} 18.15^{\prime} \mathrm{N}, 04^{\circ} 09.72^{\prime} \mathrm{W}$ & $33-36$ & $\begin{array}{c}9.1 \\
14.9\end{array}$ & $\begin{array}{l}21.02 .04 \\
17.07 .04\end{array}$ & $\begin{array}{l}23 \\
25\end{array}$ & $\begin{array}{l}0 \\
0\end{array}$ \\
\hline The Elk & $50^{\circ} 18.241^{\prime} \mathrm{N}, 04^{\circ} 10.121^{\prime} \mathrm{W}$ & $31-35$ & $\begin{array}{l}15.1 \\
11.0\end{array}$ & $\begin{array}{l}04.07 .03 \\
08.12 .04\end{array}$ & $\begin{array}{l}17 \\
20\end{array}$ & $\begin{array}{l}0 \\
0\end{array}$ \\
\hline Eddystone Rock & $50^{\circ} 10.816^{\prime} \mathrm{N}, 04^{\circ} 15.787^{\prime} \mathrm{W}$ & $25-28$ & 14.6 & 13.07 .05 & 15 & 0 \\
\hline Hand Deeps & $50^{\circ} 12.630^{\prime} \mathrm{N}, 04^{\circ} 20.360^{\prime} \mathrm{W}$ & $26-29$ & 14.3 & 18.09 .05 & 15 & 0 \\
\hline
\end{tabular}

with ASW, pH 5.5, semi-selective for fungi; (2) starch $\left(4.0 \mathrm{~g} \mathrm{l}^{-1}\right)$, peptone $\left(10.0 \mathrm{~g} \mathrm{l}^{-1}\right)$, chloramphenicol $(0.1 \mathrm{~g}$ $\mathrm{l}^{-1}$ ) and agar $\left(20.0 \mathrm{~g} \mathrm{l}^{-1}\right)$ medium made with ASW, pH 5.5, also semi-selective for fungi; (3) Marine Agar 2216 (MSA, Difco, pH 7.6), a general medium for marine bacteria; and (4) thiosulfate-citrate-bile-sucrose agar (TCBS, Oxoid, pH 8.6), a selective medium for Vibrionaceae (vibrios). Counts of colony-forming units per gram of tissue $\left(\mathrm{CFU} \mathrm{g}^{-1}\right)$ were determined after $48 \mathrm{~h}$ incubation at $20^{\circ} \mathrm{C}$. Different colony morphotypes were identified on the basis of colour, size and morphology; these were repeatedly (at least 5 times) sub-cultured from single colonies to obtain pure isolates. Pure cultures were transferred to tryptone soya agar (Oxoid) containing $1.5 \% \mathrm{NaCl}$ (TNA). For long-term storage, cultures were frozen at $-80^{\circ} \mathrm{C}$ in glycerol.
Bacterial identification. Biochemical tests were carried out using Microbact 12A/12B and API 20E (API Biomerieux) identification kits according to the manufacturer's instructions, except that $1.5 \%$ was used to prepare the inoculum. Tests were incubated at $25^{\circ} \mathrm{C}$ and read after $48 \mathrm{~h}$. For O/F (oxidation/fermentation of glucose) tests, the Hugh \& Leifson medium was adjusted to $3 \% \mathrm{NaCl}$ and incubated at $25^{\circ} \mathrm{C}$ for $24 \mathrm{~h}$. Resistance to the vibriostatic compound O/129 was assessed using discs impregnated with 10 and $150 \mu \mathrm{g}$ of O/129 (Oxoid) placed on streaked TNA plates. Growth at 0, 3 and $6 \% \mathrm{NaCl}$ was tested by inoculating tryptone soya broth (Oxoid) with appropriate $\mathrm{NaCl}$ concentrations, incubating at $26^{\circ} \mathrm{C}$ and visually assessing the opacity of the broth against reference bottles after $65 \mathrm{~h}$. Haemolytic and proteolytic activity was 
assessed by spot inoculation on TNA plates containing $5 \%$ horse blood or $1 \%$ skim milk, respectively.

DNA was extracted from overnight cultures using a Promega Wizard Genomic DNA purification kit. Amplification was carried out in an MWG thermal cycler using Promega PCR Master Mix (25 $\mu$ l reaction volume) with 10 pmol of universal bacterial primers $27 \mathrm{~F}$ and 1492R (Lane 1991); the amplification protocol was: 1 cycle at $95^{\circ} \mathrm{C}$ for $5 \mathrm{~min} ; 30$ cycles at $95^{\circ} \mathrm{C}$ for $1 \mathrm{~min}, 54^{\circ} \mathrm{C}$ for $1 \mathrm{~min}$ and $72^{\circ} \mathrm{C}$ for $2 \min$; and a final cycle of $95^{\circ} \mathrm{C}$ for $1 \mathrm{~min}, 54^{\circ} \mathrm{C}$ for $1 \mathrm{~min}$ and $72^{\circ} \mathrm{C}$ for $10 \mathrm{~min}$. PCR products were purified using a Promega Wizard SV Gel and PCR Clean-Up System and checked for purity on a $1 \%$ agarose gel. Sequencing was carried out by MWG-Biotech (Ebersberg) with either Primer 27F or 1492R. Sequences were aligned and matched using the online tools from the Ribosomal Database Project (http://rdp.cme.msu.edu/, accessed 28 June 2006). Phylogenetic trees were drawn using the Phylip interface and the maximum-likelihood method. Confirmation of identity of 2 strains by amplified fragment length polymorphism (AFLP) was carried out by Fabiano Thompson using methods he described in Thompson et al. (2003).

Infection challenge. Eunicella verrucosa clippings (50 mm) were attached to small sterile pebbles using epoxy putty (The Milliput Company) and placed individually in 11 plastic containers filled with aerated sterile ASW and kept without feeding. Clippings were inoculated by rubbing with cultures taken from agar plates (TNA, $24 \mathrm{~h}$ ) using sterile cotton swabs, and proportions of clippings affected by necrosis were recorded daily. In a preliminary experiment, clippings were maintained at 15 or $20^{\circ} \mathrm{C}$ for $15 \mathrm{~d}$ after inoculation with mixed vibrios: either CC071, CC074 and CC090 ( $\mathrm{n}=5$ ) isolated from diseased E. verrucosa colonies or CC075 and CC082 (n = 5) isolated from healthy E. verrucosa colonies. In a follow-up experiment, clippings were maintained at $20^{\circ} \mathrm{C}$ for $19 \mathrm{~d}$ and inoculated with the individual vibrio strains CC071 $(\mathrm{n}=12)$ or CC075 ( $\mathrm{n}=12)$, whereas controls $(\mathrm{n}=12)$ were sham-inoculated with swabs dipped in ASW.

Effect of bacterial extracellular products (ECP). ECP from Strain CC071 was prepared by growth on cellophane overlays on TNA $+0.5 \%$ skim milk plates $(250 \times$ $250 \mathrm{~mm}$ ) for $24 \mathrm{~h}$ at $22^{\circ} \mathrm{C}$. Cells plus ECP were removed with $15.0 \mathrm{ml}$ ice-cold phosphate-buffered saline (PBS, $3.3 \% \mathrm{NaCl}$ ) and centrifuged at $3500 \times g$ for $30 \mathrm{~min}$; supernatants were filtered with a $0.22 \mu \mathrm{m}$ membrane filter. Protease activity of ECP preparations was assayed using the azocasein assay method of Montero \& Austin (1999). The sample used had a protease activity of $100 \mathrm{U}$ (1 $\mathrm{U}=$ increase of absorbance at $540 \mathrm{~nm}$ of 0.01 $\mathrm{U}$ after $20 \mathrm{~min}$ ). The specific activity was $1300 \mathrm{U} \mathrm{mg}^{-1}$ protein (protein assay using a Sigma rapid protein quantification kit). Haemolytic activity was assessed by filling $0.7 \mathrm{~mm}$ wells in $5 \%$ horse blood-TNA plates. Clippings $(20 \mathrm{~mm}$ ) of Eunicella verrucosa were treated by immersion for $24 \mathrm{~h}$ at $22^{\circ} \mathrm{C}$ in $0.5 \mathrm{ml}$ of a preparation of ECP from Strain CC071, or in PBS (3.3\% NaCl). Release of pigment from the tissue was measured spectrophotometrically at $400 \mathrm{~nm}$ in the supernatant after centrifugation at $16000 \times g(10 \mathrm{~min})$.

\section{RESULTS}

\section{Field observations}

Video transects allowed subsequent analyses of 634 gorgonian colonies around SW England from 2003 to 2006, of which $9 \%$ had tissue necrosis (Table 1). Affected colonies had patches of necrotic tissue that were soft and white (Fig. 1A) and could easily be
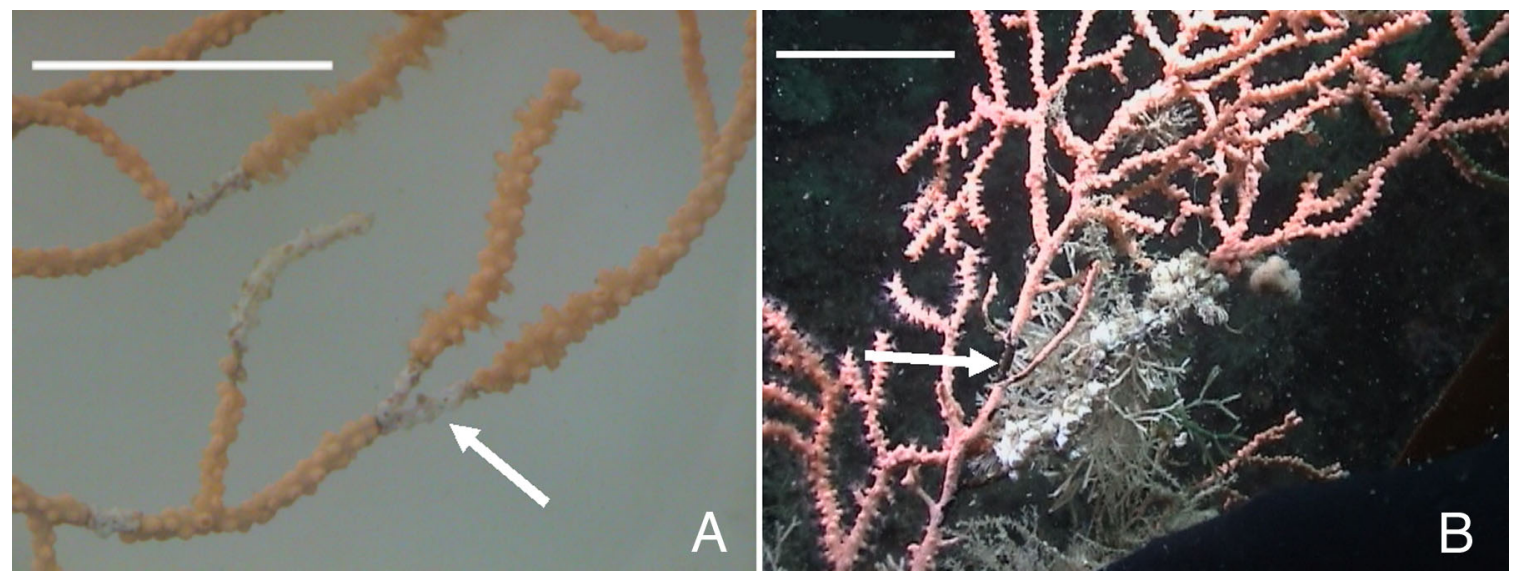

Fig. 1. Eunicella verrucosa. At $21 \mathrm{~m}$ depth at Knoll Pins, Lundy, on 16 May 2003: (A) early onset of coenchyme necrosis (arrow) and (B) post-necrotic exposure of gorgonin skeleton (arrow) with fouling community of hydroids, barnacles Solidobalanus fallax and bryozoans Cellaria sp. Scale bars $=40 \mathrm{~mm}$ 
rubbed off by hand to expose an underlying black gorgonin skeleton. Healthy gorgonians and unaffected parts of colonies with necrotic tissue damage had a tough, typically orange-pink coenchyme, which was firmly attached to the skeleton. Gorgonian necrosis was recorded at 7 out of 13 sites surveyed between 7 May 2003 and 2 June 2006 on both the north and south coasts of SW England. The disease was noted from May to October at temperatures of 12.1 to $15.3^{\circ} \mathrm{C}$ and depths of 6 to $28 \mathrm{~m}$, but was not found at depths of $>30 \mathrm{~m}$ or on the 99 colonies examined in winter (Table 1). Repeated observations made of diseased colonies at Knoll Pins, Lundy, revealed a progression, whereby necrotised tissue was sloughed allowing epibionts to colonise exposed skeleton (Fig. 1B) with remaining tissue taking on a thin, wasted appearance with a grey hue. By June 2006, 5 of the 18 colonies filmed in 2003 were dead and completely covered in epibionts, whereas the remainder were still surviving, exhibiting a dead central region overgrown by epibionts with continued colony growth at the extremities. Two new colonies (4 to $6 \mathrm{~cm}$ in height) had settled in this area and were devoid of necrosis and visible epibionts.

Organisms associated with the living coenchyme of gorgonians (as opposed to fouling organisms attached to skeletal gorgonin) comprised drift algae Dictyota dichotoma, nudibranchs Tritonia nilsodhneri), dogfish Scyliorhinus canicula eggs and squid Loligo sp. eggs and were found at sites where gorgonians were healthy as well as diseased. Most (74\%) of the 431 gorgonians recorded at sites where necrosis had been found were overgrown by a range of fouling organisms (Fig. 2) attached to dead skeletal material. Those sampled on 27 August 2003 at Mewstone Ledges at 19 to

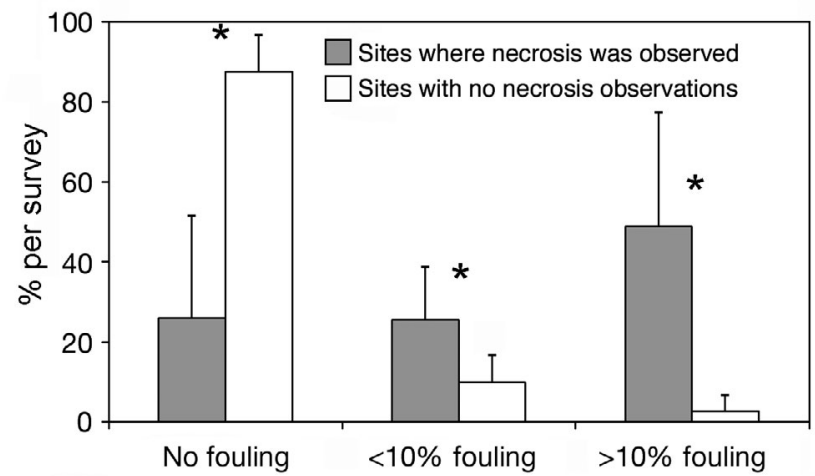

Fig. 2. Eunicella verrucosa. Proportion (+SE) of gorgonians recorded with no fouling, light fouling and heavy fouling at sites where necrosis was noted (shaded, number of dives $=20$ ) compared with sites where no necrosis was noted (unshaded, number of dives $=11$ ) between 6 and $36 \mathrm{~m}$ depth off SW England between 2003 and 2006. Significant differences $(p<0.05)$ between means indicated by asterisks
22 m depth comprised sponges (Leucosolenia complicata, Scypha compressa, Sycon ciliatum), hydroids (Aglaophenia pluma, Eudendrium rameum, Halecium spp., Lafoea dumosa, Obelia dichotoma, O. geniculata, Sertularella spp.), soft coral (Alcyonium digitatum), bryozoans (Aeta sp., Alcyonidium sp., Bugula plumosa, Cellepora hyalina, Crisia denticulata, Disporella hispida, Scrupocellaria sp., Turbicellepora avicularis), barnacles (Solidobalanus fallax) and sea squirts (Didemnidae). Results of a 1-way ANOVA showed significant differences in the proportion of seafans with no fouling $\left(F_{1,30}=48.19, \mathrm{p}<0.001\right),<10 \%$ fouling $\left(F_{1,30}\right.$ $=15.94, \mathrm{p}<0.001)$ and $>10 \%$ fouling $\left(F_{1,30}=36.07, \mathrm{p}<\right.$ $0.001)$ between sites with no necrosis observed $(n=11)$ and sites with necrosis observed $(n=21)$ (Fig. 2). Proportional data was angular transformed, tested and found to have equal variances. Whilst significantly more gorgonians were fouled at sites where necrosis had been noted, some unfouled colonies were found at these sites and were not visibly affected by disease.

\section{Ultrastructure of healthy and diseased tissue}

The coenchyme from healthy Eunicella verrucosa colonies had a thin outer layer consisting of tightly abutted balloon-club sclerites forming a tough rind overlying high concentrations of granular amoebocytes. Beneath this was a thick inner layer containing the mesoglea and granular amoebocytes, both supported structurally by spindle sclerites (Fig. 3). Necrotic coenchyme was fragile and structurally disrupted, with the balloon-club sclerites loosely packed or absent and granular amoebocytes occurring within the shrunken mesoglea of the inner coenchyme (Fig. 4). This shrinking of the mesoglea substantially reduced the spacing between spindle sclerites (Fig. 4), giving a grey, wasted appearance to diseased specimens as the black gorgonin skeleton becomes visible through the shrunken coenchyme.

\section{Microbes cultured from healthy and diseased tissue}

No fungi were isolated from any of the Eunicella verrucosa tissue samples tested, despite using culture media that were selective for fungi. On MSA media, however, far more bacteria were cultured from diseased than from healthy tissue (Fig. 5). This difference was not statistically significant, due to wide variation in bacterial numbers found between replicate tissue samples (1-way ANOVA, $F_{1,18}=3.43, \mathrm{p}=0.081$, data were arcsine transformed to achieve homogeneity of variance in the presence of zero counts). However, using TCBS media (which is semi-selective for vibrios), 


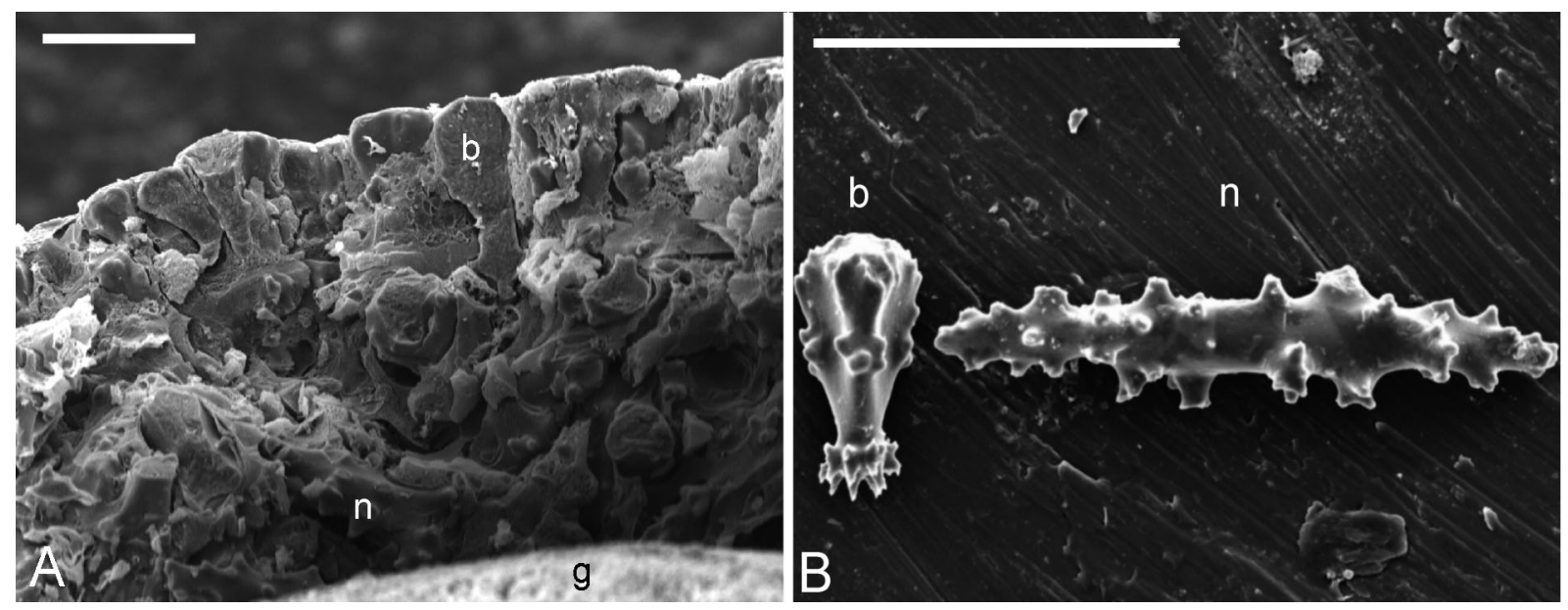

Fig. 3. Eunicella verrucosa. Collected at Mewstone Ledges at 19 to $22 \mathrm{~m}$ depth on 18 August 2005. Scanning electron microscopy of healthy tissue: (A) freeze-fracture through the coenchyme showing abutted balloon-club sclerites on the outer surface (b), skeletal gorgonin (g) and spindle sclerite (n); and (B) balloon (b) and spindle (n) sclerites. Scale bars = 50 $\mu \mathrm{m}$

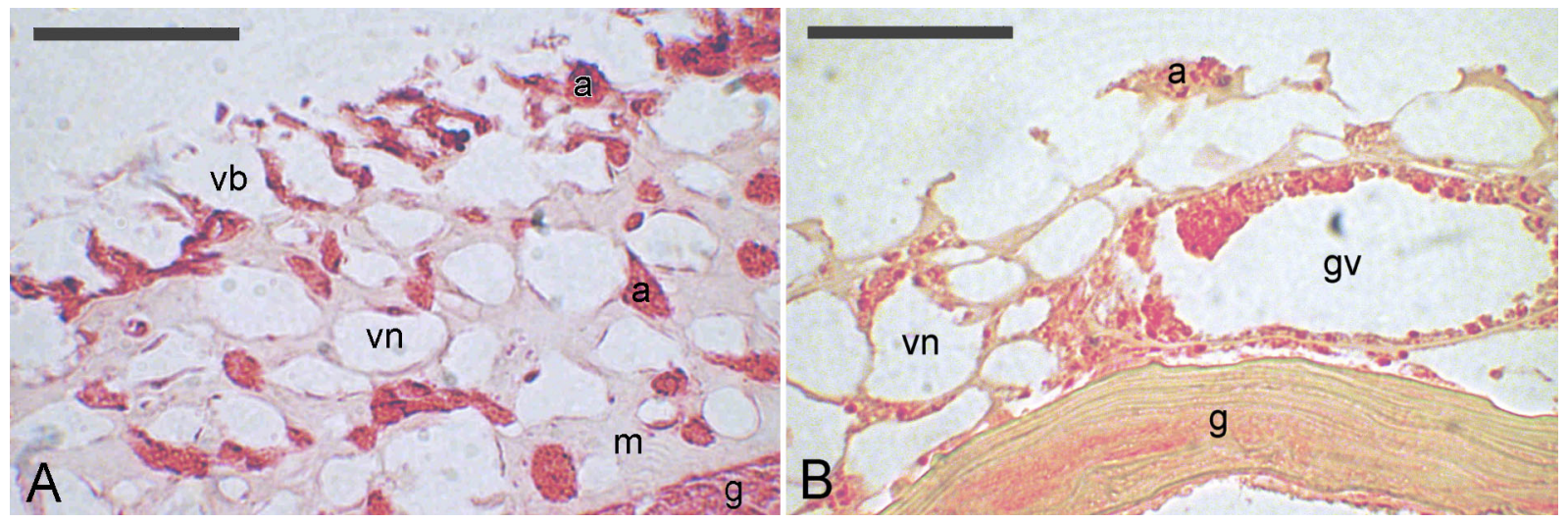

Fig. 4. Eunicella verrucosa. Collected at Mewstone Ledges at 19 to $22 \mathrm{~m}$ depth on 18 August 2005. Photomicrographs of: (A) a healthy specimen showing skeletal gorgonin $(\mathrm{g})$ overlain by coenchyme with granular amoebocytes (a), the mesoglea (m) and voids left by decalcified balloon-club (vb) and spindle sclerites (vn); and (B) a diseased specimen showing skeletal gorgonin (g) overlain by damaged coenchyme with granular amoebocytes (a) and voids left by decalcified needle sclerites (vn), which are densely packed in a shrunken mesoglea with the gastrovascular cavity (gv) surrounded by gastrodermal cells. Scale bars $=50 \mu \mathrm{m}$

significantly higher concentrations of bacteria were found in the tissues of clippings taken from diseased gorgonians than in healthy tissue samples (1-way ANOVA, $F_{1,18}=16.82, \mathrm{p}=0.001$, arcsine transformed).

\section{Identification of bacteria}

Initially, 48 colony types were distinguished on the basis of clear differences in colony colour, morphology and size. After repeated sub-culture, 21 pure cultures were eventually obtained. The remaining colony types were present in very small numbers on the initial isolation plates and became non-viable after sub-culture to obtain pure colonies. The isolated colonies predominantly had an off-white appearance (with a green hue on TCBS), forming 2 to $4 \mathrm{~mm}$ circular colonies after $38 \mathrm{~h}$. Some colonies appeared yellow on TCBS medium, indicating the metabolism of sucrose; some displayed varying colours that were usually lost on sub-culture. Colony growth and appearance on TCBS suggested that these were bacteria in the family Vibrionaceae, which was confirmed by showing that these isolates were gram-negative, oxidase positive, facultatively anaerobic, and motile (Alsina \& Blanch 1994). Most cultures isolated from Eunicella verrucosa clippings showed positive reactions for D-glucose, D-mannitol, urea, ONPG, indole, arginine and gelatine, and negative reactions for lysine, ornithine, xylose and citrate. The test for sucrose utilisation gave varied results, and none of the cultures reacted positively to the $\mathrm{H}_{2} \mathrm{~S}$, Voges Proskauer, TDA, inositol, sorbitol, rhamnose, 


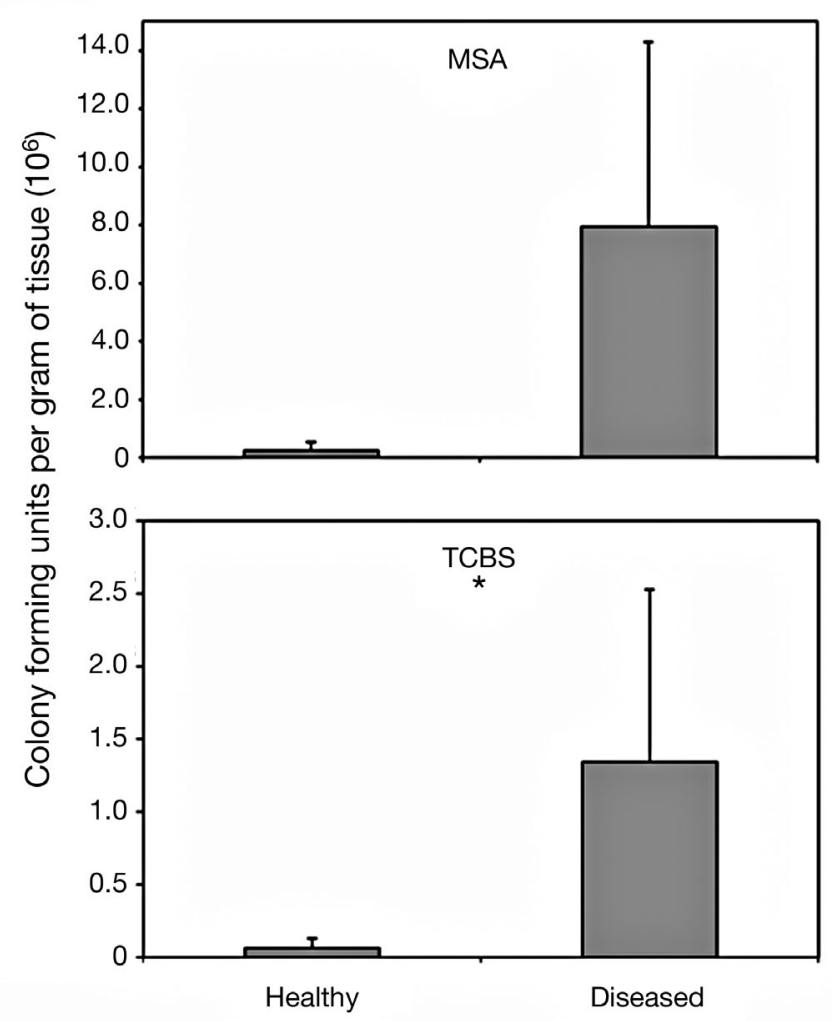

Fig. 5. Numbers of bacteria (+SE) cultured on Marine Agar 2216 (MSA) and thiosulfate-citrate-bile-sucrose agar (TCBS), from healthy $(\mathrm{n}=10)$ and diseased $(\mathrm{n}=10)$ tissue clippings from Eunicella verrucosa collected at Mewstone Ledges at 19 to $22 \mathrm{~m}$ depth on 18 August 2005. Significant difference $(p<0.01)$ between means indicated by an asterisk

salicin, lactose, or arabinose tests. Tests for growth at varying $\mathrm{NaCl}$ concentrations, resistance to O/129 and production of caseinase and haemolysin(s) proved more effective in discriminating between cultures. Use of keys for environmental Vibrio species (Alsina \& Blanch 1994) with Probabilistic Identification of Bacteria (PIB) software (Bryant 2004) did not yield reliable identifications, although several isolates had profiles characteristic of the $V$. splendidus group. Cluster analysis (unweighted pair group method using arithmetic averages) showed phenotypic differentiation between isolates from diseased and healthy E. verrucosa, and a group consisting of 13 strains was considered to include the best candidates for pathogenic activity, as the strains were present only in diseased tissue. Of 21 sequenced isolates, 15 showed $100 \%$ similarity of partial 16S rDNA gene sequences to V. splendidus (Fig. 6). Some of the isolates that give different biochemical test results were nevertheless identified as part of the large group of $V$. splendidus strains. Two strains (CC070 and CC077) showed a close match to $V$. tasmaniensis, which was also identified by AFLP fingerprinting in samples obtained in 2004 from Lundy.

\section{Infection challenge}

Eunicella verrucosa clippings maintained at $15^{\circ} \mathrm{C}$ did not develop tissue necrosis regardless with which mixtures of vibrios they were inoculated. After $15 \mathrm{~d}$ at $20^{\circ} \mathrm{C}$ necrosis was evident in $60 \%$ of samples inoculated with a mixture of vibrios originating from diseased colonies (CC071, CC074 and CC090) and in $80 \%$ of samples inoculated with vibrios isolated from healthy specimens (CC075 and CC082). Necrosis occurred after $4 \mathrm{~d}$ in $40 \%$ of clippings inoculated with CC071, CC074 and CC090; all the remaining clippings that became necrotic did so in 11 to $13 \mathrm{~d}$.

After $19 \mathrm{~d}$ at $20^{\circ} \mathrm{C}$ no control clippings ( $\mathrm{n}=12$ ) became necrotic, whereas those inoculated with single vibrio strains, CC071 ( $\mathrm{n}=12)$ and CC075 ( $\mathrm{n}=12)$, became necrotic in 67 and $58 \%$ of the cases, respectively. A chi-squared goodness-of-fit test showed a significant difference in the occurrence of necrosis between the controls, those inoculated with CC071 and those inoculated with CC075 $\left(\chi^{2}=13.029\right.$, df $=2$, $\mathrm{p}<0.01)$. There was no significant difference in the incidence of necrosis between clippings inoculated with the vibrio strains CC071 and CC075 $\left(\chi^{2}=0.177\right.$, $\mathrm{df}=1, \mathrm{p}>0.05)$, nor in the proportion of tissue affected by necrosis (CC071: $65.8 \pm 12.6 \%$; CC075: $48.3 \pm$ $12.4 \%$; mean $\pm \mathrm{SE}$; 1 -way ANOVA, $F_{1,20}=2.26, \mathrm{p}=$ 0.148 , data angular transformed prior to statistical testing). Clippings inoculated with single vibrio strains did not become necrotic until the Day 9 after inoculation. A 1-way ANOVA showed no significant difference in the timing of the onset of necrosis between clippings inoculated with either CC071 or CC075 (12.7 \pm 1.0 and $11.8 \pm 0.4 \mathrm{~d}$, respectively; mean $\pm \mathrm{SE} ; F_{1,13}=0.38, \mathrm{p}=$ $0.55)$. In these experiments, the progression of necrosis was similar to that observed in the field, i.e. coenchyme tissue lost colour, became fragile and sloughed from the skeleton. This process began at discreet points on the clippings and from these points progressed outwards in both directions.

\section{Effect of bacterial ECP}

There was a visible colour and opacity difference between ECP preparations and controls following immersion of Eunicella verrucosa clippings for $24 \mathrm{~h}$. ECP induced shrivelling of the tissue, and the damage was evident through the release of pink-orange pigment, which was quantified by spectrophotometric measurement at $400 \mathrm{~nm}$. A 1-way ANOVA showed that the ECP caused a significantly higher release of pigment than the control $\left(F_{1,18}=37.39, \mathrm{p}<0.001\right.$; exposed: $0.27 \pm 0.09$ abs (absorption units); control $0.05 \pm 0.09$ abs; mean $\pm \mathrm{SD})$. 


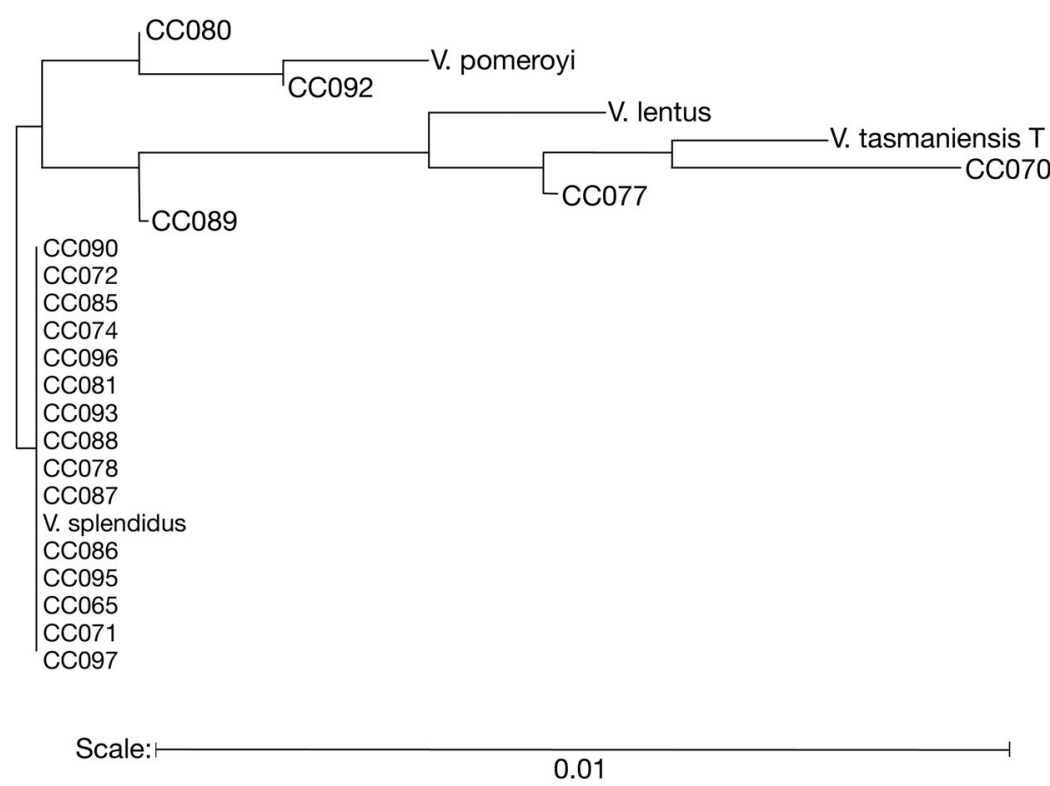

Fig. 6. Phylogenetic tree showing relationships of 21 isolates of bacteria from Eunicella verrucosa to strains of Vibrio spp. Tree is based on the maximumlikelihood method using partial 16S rDNA sequences, aligned and matched using the online tools from the Ribosomal Database Project

area was dead, many colonies brought in were partially dead, none in such good condition as in the previous July' (Marine Biological Association 1957).

The nature of Eunicella verrucosa disease was similar to that reported during outbreaks of gorgonian disease in the Caribbean and the Mediterranean (Cerrano et al. 2000, Kim \& Harvell 2004). As in those regions, the disease manifested itself as patches of necrosis; the coenchyme became soft and lost structural integrity, sloughing away from the gorgonin skeleton and allowing fouling organisms to colonise. Fouling communities were diverse, but dominated by hydroids, bryozoans and Solidobalanus fallax barnacles, an invasive southern species only recently recorded in SW England (Southward et al. 2004). Low incidences of fouled colonies were found at sites where necrosis was not seen, suggesting that disease might not be the only trigger for fouling communities to colonise gorgonians. However, numbers

\section{DISCUSSION}

Corals are highly diverse and widespread in coldwater areas such as high-latitude and deep-sea regions of the oceans (Cairns \& Chapman 2001, Watling \& Auster 2005, Bryan \& Metaxas 2007, Hall-Spencer et al. 2007). Scleractinian and gorgonian corals, in particular, can form dense stands in cold-water regions, increasing the structural complexity of habitats and thereby contributing strongly to their biodiversity, just as they do on tropical coral reefs (Roberts et al. 2006, Rogers et al. 2007). Current threats to cold-water coral communities include trawling (Hall-Spencer et al. 2002) and climate-driven changes in ocean chemistry (Guinotte et al. 2006), but the effects of disease on such communities are unknown.

An outbreak of Eunicella verrucosa disease, first recorded at Lundy marine reserve in 2002, was not an isolated incident, but occurred again in the summer months of 2003 to 2005, both in the Bristol Channel and at 6 English Channel sites. It seems unlikely that previous outbreaks of E. verrucosa disease would have gone unnoticed in recent years at Lundy marine reserve as the gorgonians are monitored by divers (Hiscock 2003), although outbreaks could have been overlooked in other areas. A widespread die-back of $E$. verrucosa that may have been related to disease was recorded during standard trawls of the Marine Biological Association UK in 1924, when it was noted that 'a great amount of Eunicella brought up in the Plymouth of unfouled colonies were significantly higher at sites where necrosis had not been seen.

The nearest reports of disease in other gorgonian species are from the NW Mediterranean, with mass mortalities recorded in 1999 during a period of unusually high sea-water temperatures (Cerrano et al. 2005, Linares et al. 2005). Increased incidences of coral disease have also been linked to high-temperature events in the tropics, which may be attributable to the effects of global warming (Harvell et al. 2002, Rosenberg \& Ben Haim 2002), although nutrient enrichment is also known to increase the severity of tropical coral diseases (Bruno et al. 2003). As with NW Mediterranean outbreaks, we only recorded gorgonian disease in warmer months and in shallow-water populations, although maximum in situ temperatures recorded around the gorgonians (to $15.4^{\circ} \mathrm{C}$ ) were not unusual for the area.

Our attempts to isolate microorganisms that may have caused Eunicella verrucosa necrosis started with a search for fungal agents, as the only proven aetiological agent of gorgonian necrosis is the fungus Aspergillus sydowii in the Caribbean (Kim \& Harvell 2004). We found no evidence for fungal involvement in E. verrocosa necrosis, although it is possible that disease was caused by fungi that could not be cultured using the media and incubation conditions used. However, Vibrionaceae bacteria formed a dominant proportion of the culturable microbiota of diseased $E$. verrucosa and were found at significantly higher num- 
bers than in healthy tissue. The TCBS medium we used is ideal for isolation and purification of vibrios, with distinction according to sucrose fermentation, although some other bacteria may present slight growth (Thompson et al. 2005a). Several strains initially isolated on general-purpose MSA medium were shown to grow on TCBS and were subsequently identified as vibrios. Using $16 \mathrm{~S}$ rDNA typing, we found that most of the isolates tested were strains of Vibrio splendidus. This is striking because Martin et al. (2002) also isolated V. splendidus and a number of other Vibrio spp. from diseased tissues of the gorgonians Paramuricea clavata and Eunicella cavolinii in their study of mass mortality in NW Mediterranean gorgonians. It should be noted that 16S rDNA sequencing gives insufficient discrimination among species, and further analysis should be conducted using multilocus sequence analysis (Thompson et al. 2005a).

Vibrionaceae have also been implicated in diseases of warm-water scleractinians such as white band disease (Ritchie \& Smith 1998) and yellow blotch/band disease (Cervino et al. 2004) and have been associated with coral bleaching (Thompson et al. 2005b). Vibrio shiloi and $V$. coralliilyticus are respectively known to cause bleaching and necrosis in Oculina patagonica in the Mediterranean (Kushmaro et al. 1997) and Pocillopora damicornis in the Indian Ocean and Red Sea (Ben Haim et al. 2003). The occurrence of both infections has been related to elevated seawater temperatures (Israely et al. 2001). As well as being coral pathogens, Vibrionaceae can be a normal component of the microbiota of corals, but may increase in numbers during disease, with environmental factors such as elevated temperature causing the expression of virulence factors (Bourne \& Munn 2005).

Martin et al. (2002) were able to induce tissue necrosis at elevated temperatures in Paramuricea clavata and Eunicella cavolinii with 5 of the vibrio strains they isolated from diseased gorgonian tissue. However, they did not examine the microbiology of the gorgonians not affected by disease. In our attempts to find out whether vibrios were the causative agents of infection in E. verrucosa, a mix of the 3 isolates most commonly found in diseased tissue and individual inoculation with one of these isolates led to necrosis in some inoculated specimens at higher temperatures. It is important to note that the temperature during this experiment is above the maximum experienced by the seafans in the field. In any case, infection also proved to be inducible using vibros isolated from healthy E. verrucosa colonies at $20^{\circ} \mathrm{C}$, so we were therefore unable to fulfil Koch's postulates to prove aetiology. Similar difficulties in establishing aetiology have been reported for other coral diseases (Richardson 1998, Richardson et al. 2001, Ritchie et al.
2001). It appears that, when stressed, E. verrucosa becomes vulnerable to the pathogenic activity of these vibrios. In these experiments, the induced stress was elevated temperature. It is noteworthy that Cervino et al. (2004) found that when the coral Montastraea sp. was inoculated with 4 Vibrio spp. together, signs of disease occurred more quickly and more closely matched infection in the field, suggesting that these 4 species act as a consortium. The tissue samples examined in our study were often in an advanced state of necrosis. Without sampling zones immediately adjacent to the living tissue as the disease progresses, it is not possible to ascertain whether vibrios are primary colonisers and a cause of the condition, or whether they are a secondary effect.

Our in situ observations that some colonies appeared unaffected by disease despite being surrounded by necrotic specimens suggests differences in the susceptibility of individual gorgonians to infection. Anthozoa defend against microbial infection though epidermal mucilage production, the synthesis of antimicrobial compounds and an amoebocyte response (Mullen et al. 2004). The high concentration of amoebocytes we observed in Eunicella verrucosa coenchyme may have phagocytotic and wound-healing potential as shown in another gorgonian species (Olano \& Bigger 2000, Kelman 2004). There is also evidence for a range of antibacterial and antifungal activity in other gorgonians (Jensen et al. 1996, Harvell et al. 2001). It is possible that the disease process is initiated by breakdown in host resistance and infection by an unknown microbe and that tissue colonisation by a mixed population of Vibrionaceae is a secondary effect. It is notable that the majority of Vibrio isolates were potent producers of proteolytic and cytolytic compounds (assessed in vitro by haemolysis) and that isolated ECP (containing crude protease) caused extensive tissue damage. A number of culture-independent studies of microbial communities associated with corals have been performed in recent years (Cooney et al. 2002, Frias-Lopez et al. 2002, Rohwer \& Kelley 2004, Bourne \& Munn 2005), indicating that corals may form specific multi-species symbioses with bacterial communities (Knowlton \& Rohwer 2003) and that disturbance of the normal microbiota may be responsible for disease. GilAgudelo et al. (2006) showed changes in the bacterial communities are associated with aspergillosis infection of Gorgonia ventalina. The possibility of virus infection should also be considered. Although viral diseases having been reported for a wide variety of marine organisms (Munn 2006), there are only a few observations of virus-like particles in Anthozoa; the cold-water anemones Metridium senile (Wilson \& Chapman 2001) and Anemonia viridis (Wilson et al. 2001) and in tropical scleractinians Pavona danai (Wilson et al. 2005) and 
Montastraea spp. suffering yellow band/blotch disease (Cervino et al. 2004).

The disease outbreaks recorded in SW England have so far not been as devastating to gorgonian populations as the mass mortality events recorded in the Caribbean in 1994 and in the NW Mediterranean in 1999. Eunicella verrucosa recruitment was noted in areas affected by disease, despite outbreaks being recorded each summer in 2003 to 2005, and many of the colonies affected in SW England showed regeneration around damaged parts of affected colonies. There were also numerous sites in the region that showed no evidence of disease outbreak. However, both Linares et al. (2005) and Cerrano et al. (2005) noted that sublethal effects of gorgonian disease can have long-term effects on regional benthic ecology. Effects can be long-lasting because gorgonian corals are typically slow-growing, high-biomass organisms that contribute to the 3-dimensional complexity of the benthic habitat. Clearly, our first observations of localised disease outbreaks in E. verrucosa indicate that coral diseases may be widespread in cold-water regions of the planet and that vigilance is required to assess their causes and effects.

Acknowledgements. Thanks to K. Hiscock for alerting us to the disease outbreak, E. Peters for histological advice, F. Thompson for bacterial identifications, S. Lindsey-Leake for epibiont identifications, L. Dallas for help during a Society of General Microbiology studentship and the Coxside diving support staff at the University of Plymouth. We acknowledge research grants to J.H.-S. from English Nature, the Esmee Fairbairn Foundation and the Royal Society.

\section{LITERATURE CITED}

Alsina M, Blanch AR (1994) Improvement and update of a set of keys for biochemical identification of Vibrio species. J Appl Bacteriol 77:719-721

Ben Haim Y, Zicherman-Keren M, Rosenberg E (2003) Temperature-regulated bleaching and lysis of the coral Pocillopora damicornis by the novel pathogen Vibrio coralliilyticus. Appl Environ Microbiol 69:4236-4242

Bourne DG, Munn CB (2005) Diversity of bacteria associated with the coral Pocillopora damicornis from the Great Barrier Reef. Environ Microbiol 7:1162-1174

Bruno JF, Petes LE, Harvell CD, Hettinger A (2003) Nutrient enrichment can increase the severity of coral diseases. Ecol Lett 6:1056-1061

Bryan TL, Metaxas A (2007) Predicting suitable habitat for deep-water gorgonian corals on the Atlantic and Pacific Continental Margins of North America. Mar Ecol Prog Ser 330:113-126

Bryant TN (2004) Letter to the editor. J Appl Microbiol 97: 1326-1327

Bucke D (1989) Histology. In: Austin B, Austin DA (eds) Methods for the microbiological examination of fish and shellfish. Ellis-Horwood, Chichester, p 69-97

Cairns SD, Chapman RE (2001) Biogeographic affinities of the North Atlantic deep-water Scleractinia. In: Willison JHW,
Hall J, Gass SE, Kenchington ELR, Butler M, Doherty P (eds) Proceedings of the 1st international symposium on deep-sea corals. Ecology Action Centre, Halifax, p 30-57

Cerrano C, Bavestrello G, Bianchi CN, Cattaneo-Vietti R and 8 others (2000) A catastrophic mass-mortality episode of gorgonians and other organisms in the Ligurian Sea (northwestern Mediterranean), summer 1999. Ecol Lett 3: 284-293

Cerrano C, Arillo A, Azzini F, Calcinai B and 5 others (2005) Gorgonian population recovery after a mass mortality event. Aquat Conserv Mar Freshw Ecosyst 15:147-157

Cervino JM, Hayes RL, Polson SW, Polson SC, Goreau TJ, Martinez RJ, Smith GW (2004) Relationship of Vibrio species infection and elevated temperatures to yellow blotch/band disease in Caribbean corals. Appl Environ Microbiol 70:6855-6864

Cooney RP, Pantos O, Le Tissier MDA, Barer MR, O'Donnell AG, Bythell JC (2002) Characterisation of the bacterial consortium associated with black band disease in coral using molecular microbiological techniques. Environ Microbiol 4:401-413

Frias-Lopez J, Zerkle AL, Bonheyo GT, Fouke BW (2002) Partitioning of bacterial communities between seawater and healthy, black band diseased, and dead coral surfaces. Appl Environ Microbiol 68:2214-2228

Garrison VH, Shinn EA, Foreman WT, Griffin DW and 6 others (2003) African and Asian dust: from desert soils to coral reefs. Bioscience 53:469-480

Geiser DM, Taylor JW, Ritchie KB, Smith GW (1998) Cause of sea fan death in the West Indies. Nature 394:137-138

Gil-Agudelo DL, Myers C, Smith GW, Kim K (2006) Changes in the microbial communities associated with Gorgonia ventalina during aspergillosis infection. Dis Aquat Org 69: $89-94$

Guinotte JM, Orr J, Cairns S, Freiwald A, Morgan L, George R (2006) Will human-induced changes in seawater chemistry alter the distribution of deep-sea scleractinian corals? Front Ecol Environ 4:141-146

Hall-Spencer J, Allain V, Fossa JH (2002) Trawling damage to Northeast Atlantic ancient coral reefs. Proc R Soc Lond B 269:507-511

Hall-Spencer J, Rogers A, Davies J, Foggo A (2007) Deep-sea coral distribution on seamounts, oceanic islands and continental slopes in the NE Atlantic. Bull Mar Sci 80: in press

Harvell CD, Mitchell CE, Ward JR, Altizer S, Dobson AP, Ostfeld RS, Samuel MD (2002) Climate warming and disease risks for terrestrial and marine biota. Science 296: 2158-2162

Harvell D, Kim K, Quirolo C, Weir J, Smith G (2001) Coral bleaching and disease: contributors to 1998 mass mortality in Briareum asbestinum (Octocorallia, Gorgonacea). Hydrobiologia 460:97-104

Hiscock K (2003) Where have all the corals gone? Mar Conserv 6:8-9

Israely T, Banin E, Rosenberg E (2001) Growth, differentiation and death of Vibrio shiloi in coral tissue as a function of seawater temperature. Aquat Microb Ecol 24:1-8

IUCN (International Union for Conservation of Nature and Natural Resources) (2006) IUCN red list of threatened species. Available from www.iucnredlist.org (accessed on 28 June 2006)

Jensen PR, Harvell CD, Wirtz K, Fenical W (1996) Antimicrobial activity of extracts of Caribbean gorgonian corals. Mar Biol 125:411-419

Kelman D (2004) Antimicrobial activity of sponges and corals. In: Rosenberg E, Loya Y (eds) Coral health and disease. Springer, Heidelberg, p 244-263 
Kim K, Harvell CD (2004) The rise and fall of a six-year coral-fungal epizootic. Am Nat 164:52-63

Knowlton N, Rohwer F (2003) Multispecies microbial mutualisms on coral reefs: the host as a habitat. Am Nat 162: 51-62

Kushmaro A, Rosenberg E, Fine M, Loya Y (1997) Bleaching of the coral Oculina patagonica by Vibrio AK-1. Mar Ecol Prog Ser 147:159-165

Lane DJ (1991) 16S/23S rRNA sequencing. John Wiley \& Sons, Chichester

Linares C, Coma R, Diaz D, Zabala M, Hereu B, Dantart L (2005) Immediate and delayed effects of a mass mortality event on gorgonian population dynamics and benthic community structure in the NW Mediterranean Sea. Mar Ecol Prog Ser 305:127-137

Marine Biological Association (1957) Plymouth Marine Fauna, 3rd edn. Plymouth

Martin Y, Bonnefort JL, Chancerelle L (2002) Gorgonians mass mortality during the 1999 late summer in French Mediterranean coastal waters: the bacterial hypothesis. Water Res 36:779-782

Montero AB, Austin B (1999) Characterization of extracellular products from an isolate of Vibrio harveyi recovered from diseased post-larval Penaeus vannamei (Bonne). J Fish Dis 22:377-386

Mullen KM, Peters EC, Harvell CD (2004) Coral resistance to disease. In: Rosenberg E, Loya Y (eds) Coral health and disease. Springer, Heidelberg, p 377-399

Munn CB (2004) Marine microbiology: ecology and applications. Garland Science/BIOS Scientific Publishers, Abingdon and New York

Munn CB (2006) Viruses as pathogens of marine organisms from bacteria to whales. J Mar Biol Assoc UK 86:453-467

Nagelkerken I, Buchan K, Smith GW, Bonair K and 10 others (1997) Widespread disease in Caribbean sea fans: II. Patterns of infection and tissue loss. Mar Ecol Prog Ser 160: 255-263

Olano CT, Bigger CH (2000) Phagocytic activities of the gorgonian coral Swiftia exserta. J Invertebr Pathol 76: 176-184

Richardson LL (1998) Coral diseases: What is really known? Trends Ecol Evol 13:438-443

Richardson LL, Smith GW, Ritchie KB, Carlton RG (2001) Integrating microbiological, microsensor, molecular, and physiologic techniques in the study of coral disease pathogenesis. Hydrobiologia 460:71-89

Ritchie KB (2006) Regulation of microbial populations by coral surface mucus and mucus-associated bacteria. Mar Ecol Prog Ser 322:1-14

Editorial responsibility: Richard Cawthorn, Charlottetown, Prince Edward Island, Canada
Ritchie KB, Smith GW (1998) Type II white-band disease. Rev Biol Trop 46:199-203

Ritchie KB, Polson SW, Smith GW (2001) Microbial disease causation in marine invertebrates: problems, practices, and future prospects. Hydrobiologia 460:131-139

Roberts JM, Wheeler AJ, Freiwald A (2006) Reefs of the deep: the biology and geology of cold-water coral ecosystems. Science 312:543-547

Rogers AD, Baco A, Griffiths, H, Hall-Spencer JM (2007) Corals on seamounts. In: Pitcher TJ, Hart PJB, Morato T, Santos R, Clark M (eds) Seamounts: ecology fisheries and conservation. Blackwell Fisheries and Aquatic Resources Series, Blackwell Scientific, Oxford, p 141-169

Rohwer F, Kelley S (2004) Culture-independent analyses of coral-associated microbes. In: Rosenberg E, Loya Y (eds) Coral health and disease. Springer-Verlag, New York, p 264-277

Rosenberg E, Ben Haim Y (2002) Microbial diseases of coral and global warming. Environ Microbiol 4:318-326

Southward AJ, Hiscock K, Kerckhof F, Moyse J, Elfimov AS (2004) Habitat and distribution of the warm-water barnacle Solidobalanus fallax (Crustacea: Cirripedia). J Mar Biol Assoc UK 84:1169-1177

Thompson FL, Thompson CC, Swings J (2003) Vibrio tasmaniensis sp. nov., isolated from Atlantic salmon (Salmo salar L.). Syst Appl Microbiol 26:65-69

Thompson FL, Gevers D, Thompson CC, Dawyndt P, Naser S, Hoste B, Munn CB, Swings J (2005a) Phylogeny and molecular identification of vibrios based on multilocus sequence analysis. Appl Environ Microbiol 77 : 5107-5115

Thompson FL, Thompson CC, Naser S, Hoste B, Vandemeulebroecke K, Munn C, Bourne D, Swings J (2005b) Photobacterium rosenbergii sp. nov. and Enterovibrio coralii sp. nov., vibrios associated with coral bleaching. Int J Syst Evol Microbiol 55:913-917

Watling L, Auster PJ (2005) Distribution of deep-sea Alcyonacea off the northeast coast of the United States. In: Freiwald A, Roberts JM (eds) Cold-water corals and ecosystems. Springer-Verlag, Heidelberg, p 279-296

Wilson WH, Chapman DM (2001) Observation of virus-like particles in thin sections of the plumose anemone, Metridium senile. J Mar Biol Assoc UK 81:879-880

Wilson WH, Francis I, Ryan K, Davy SK (2001) Temperature induction of viruses in symbiotic dinoflagellates. Aquat Microb Ecol 25:99-102

Wilson WH, Dale AL, Davy JE, Davy SK (2005) An enemy within? Observations of virus-like particles in reef corals. Coral Reefs 24:145-148

Submitted: July 18, 2006; Accepted: March 14, 2007

Proofs received from author(s): June 25, 2007 